
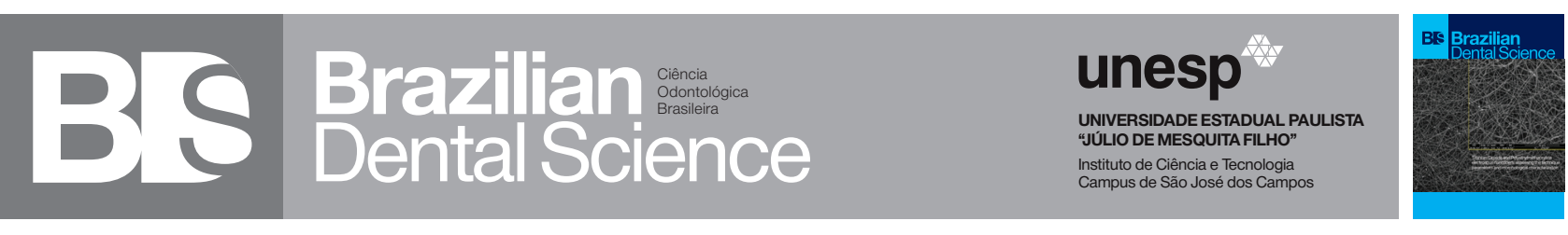

\title{
Systemic Health Characteristics and Self-Reported Xerostomia among Nursing Facility Residents in lowa-US and Sao Paulo-Brazil
}

Saúde Sistêmica e Xerostomia Auto-Reporada entre Residentes em Instituições de Longa Permanência em lowa-EUA e São Paulo-Brasil

Erica RECKER ${ }^{1}$, Mariana Sarmet Smiderle MENDES ${ }^{2}$, Derek BLANCHETTE ${ }^{3}$, Deborah DAWSON ${ }^{4}$, Howard COWEN ${ }^{5}$, Jennifer HARTSHORN $^{5}$, Jarbas Francisco Fernandes dos SANTOS ${ }^{6}$, Leandro Notari CHESTER ${ }^{6}$, Daniel CAPLAN 5 , Leonardo MARCHINI $^{5}$

1 - University of Iowa College of Dentistry \& Dental Clinics - Iowa City - IA - USA.

2 - Multiprofessional Program of Health and Palliative Care for Elderly - School of Medicine - University of São Paulo - São Paulo - SP - Brazil.

3 - Division of Biostatistics and Computational Biology - University of Iowa College of Dentistry \& Dental Clinics - Iowa City - IA - USA.

4 - Iowa Institute for Oral Health Research - University of Iowa College of Dentistry \& Dental Clinics - Iowa City - IA - USA.

5 - Department of Preventive Dentistry - University of Iowa College of Dentistry \& Dental Clinics - Iowa City - IA - USA.

6 - University of Taubaté - Taubaté - SP - Brazil.

\section{ABSTRACT}

Objective: To describe and compare potential differences in systemic health characteristics and xerostomia among residents in American and Brazilian nursing facilities (NF). Material and Methods: This secondary analysis used data from a study in NF located in Iowa-USA $(n=81)$ and Sao Paulo (SP)-Brazil $(n=119)$. Recorded data included demographics, medications, comorbid conditions, and self-reported xerostomia. Results: The Iowa group mean age was 82.1 years $( \pm 12.9), 60.5 \%$ were females, and $100 \%$ were white, whereas the SP group mean age was 76.4 years $( \pm 8.7), 47.9 \%$ females, most participants identified as either white $(42.0 \%)$ or as more than one race (45.4\%). The median number of comorbid conditions and medications in the Iowa were 9 and 12, respectively, as compared to 2 and 6 in SP. Most common comorbidities in Iowa were hypertension, dementia (including Alzheimer), and depression. In SP, they were hypertension, unspecified diabetes mellitus (including type 2), and Parkinson. Most common prescription medications in Iowa were acetaminophen, acetylsalicylic acid, and magnesium hydroxide, while in SP, they were omeprazole, acetylsalicylic acid, and losartan. Xerostomia was reported by $32.1 \%$ (Iowa) and $59.7 \%$ (SP) of the participants. There was no association between age and dry mouth sensation in either Iowa $(\mathrm{p}=0.480)$ or $\mathrm{SP}(\mathrm{p}=0.130)$ samples. However, there was an association between total medications

\section{RESUMO}

Objetivo: Descrever e comparar possíveis diferenças nas características de saúde sistêmica e xerostomia entre residentes em instituições de longa permanência (ILP) americanas e brasileiras. Materiais e Métodos: Esta análise utilizou dados de um estudo em ILPs localizadas em Iowa/EUA $(n=81)$ e São Paulo/Brasil $(n=119)$. Os dados avaliados incluíram dados demográficos, medicamentos, comorbidades e xerostomia autoreportada. Resultados: A idade média do grupo de Iowa foi de 82,1 anos ( $\pm 12,9), 60,5 \%$ eram do sexo feminino e $100 \%$ eram brancos, enquanto a idade média do grupo SP foi de 76,4 anos ( $\pm 8,7), 47,9 \%$ do sexo feminino, a maioria dos participantes identificados como brancos $(42,0 \%)$ ou como mais de uma raça $(45,4 \%)$. A média do número de comorbidades e medicamentos em Iowa foi de 9 e 12, respectivamente, em comparação com 2 e 6 em SP. Comorbidades mais comuns em Iowa foram hipertensão, demência (incluindo Alzheimer) e depressão. Em SP, foram hipertensão, diabetes mellitus (incluindo o tipo 2) e Parkinson. Os medicamentos de prescrição mais comuns em Iowa eram acetaminofeno, ácido acetilsalicílico e hidróxido de magnésio, enquanto em SP, foram omeprazol, ácido acetilsalicílico e losartana. A xerostomia foi reportada por $32,1 \%$ dos participantes em Iowa e 59,7\% em SP. Não houve associação entre idade e sensação de boca seca nas amostras de Iowa $(\mathrm{p}=0,480)$ ou $\mathrm{SP}(\mathrm{p}=$ 0,130 ). No entanto, houve associação entre o total de medicamentos e a sensação de boca seca em Iowa (p 
and dry mouth sensation in Iowa $(\mathrm{p}=0.040)$, but not in $S P(p=0.075)$ Conclusions: Iowans presented with higher numbers of comorbidities and prescription medications, however xerostomia was reported in a greater percentage in SP. Xerostomia was associated to higher number of medications in Iowa, but not in SP.

\section{KEYWORDS}

Xerostomia; Aged; frail elderly; Nursing homes.
$=0,040)$, mas não em SP ( $p=0,075)$. Conclusões: Os residentes de Iowa apresentaram maior número de comorbidades e prescrição de medicamentos, porém a xerostomia foi relatada em maior percentual em SP. A xerostomia foi associada ao maior número de medicamentos em Iowa, mas não em SP.

\section{PALAVRAS-CHAVE}

Xerostomia; Envelhecimento; Idoso frágil; Instituções de longa permanência.

\section{INTRODUCTION}

Dopulation aging is a worldwide phenomenon 1 [1]. For example, the US had about 47.8 million elderly individuals (those 65-year old or older) in 2015 , or $14.9 \%$ of the American population [2]. In Brazil, the elderly group accounted for $12.1 \%$ of Brazilian population in the same year. [3]

Although the proportions of these two elderly populations may look similar, the aging process occurred in a longer period of time in developed nations versus a much shorter length of time in developing nations. It took the USA 69 years (19442013) to increase the proportion of the elderly in its total population from $7 \%$ to $14 \%$. The same growth is projected to happen in 21 years in Brazil (2011-2032) [4], and Brazil may achieve the 14\% mark even earlier. This difference in the aging time frames has indeed resulted in other significant differences among developed and developing nations regarding elderly well-being. For instance, health care delivery systems have been greatly affected, and older adults institutionalization rates present with great variability.

As the elderly population grows, more elders are expected to reside in nursing facilities (NF). In Brazil, only 83,870 elderly individuals were institutionalized in 2009 [5] (0.5\% of the Brazilian elderly population at that time). In the USA, the nursing facilities population was over 1.4 million residents in 2014 (2.6\% of the American elderly population at that time) [6]. In addition, the USA presents a large network of NF well- distributed throughout the 50 states [6], while Brazil has a third of its NF concentrated in one of 26 Brazilian states (State of Sao Paulo) [5]. As developing nations face the aging challenges with scarce resources, they may benefit from the experiences developed nations have had with providing health care to their elderly populations. By adapting successful initiatives to their specific contexts and avoiding failed models, there is potential for improvement.

One of the most important reasons for elderly people's institutionalization is multimorbidity, which results in higher degree of dependency. As people age, there is a significant increase in the prevalence of chronic diseases, such as dementia, depression, arthritis, diabetes, cardiovascular diseases, Parkinsonism, and cancers, among others [1,7]. Multimorbidity usually demands more intensive health care, in particular for demented patients, thus requiring institutionalization [8].

Multimorbidities also affect oral health in many ways, and the resulting use of multiple medications (polypharmacy) administered to treat multiple diseases may lead to xerostomia [7,9].

Saliva is of paramount importance for oral health and oral-health related quality of life. Salivary roles include enzymatic digestion, remineralization of teeth, modulation of microorganisms' populations, lubrication during mastication, thus preserving and protecting oral mucosal tissues [10]. However, previous studies have reported that as people age, the unstimulated salivary flow 
rate will decrease due to atrophy of salivary glands [11]. In particular, the submandibular salivary gland, responsible for $70 \%$ of the resting saliva flow, has been found to have decreasing cellular activity and secretory functions with advanced age $[12,13]$. However, other studies have shown the saliva buffering capacity to the bicarbonate found in saliva is not related to age [14]. Alpha amylase is another component of saliva which shows no changes when related to natural aging. The alpha amylase is mainly produced by the parotid glands, and reports have shown that the parotid gland can maintain its secretory function over the human life span [10].

When comparing elderly patients who are healthy and taking minimal medications compared to those taking multiple xerostomic medications, Leal et al. [15] measured the stimulated and unstimulated salivary flow in patients. It appears that unstimulated salivary flow rate significantly decreases with the usage of xerostomic medications. However, the stimulated salivary flow between elderly patients taking xerostomic medications and healthy elderly without medications show no statistical difference [15]. It is thought that with gustatory stimulation of the body can overcome a low unstimulated salivary flow rate. It should be kept in mind that xerostomic symptoms may occur without measurable reduction in salivary gland output $[15,16]$.

Although oral health conditions, including xerostomia, are reportedly related to general wellbeing $[17,18]$, poor oral health and lack of oral health care are commonplace in NF worldwide [19-21]. Consequently, there is a great need for delivering effective oral health care to NF residents. Many oral health professionals are afraid of treating systemically complex elderly patients [22], though learning about NF residents' systemic health conditions may add to oral health professionals' knowledge and understanding of NF residents' needs. In addition, observing the differences in systemic health conditions among NF residents in both developed and developing nations may aid in preparing proper oral health care delivery systems for both current and future needs.

This paper aims to present and compare systemic health characteristics and xerostomia profiles of NF residents from the State of Iowa, USA, and the State of Sao Paulo, Brazil. Based on previous reports $[7,9,23,24]$, our hypothesis is that more co-morbidities and more medications are present among the American population. Furthermore, we expect that the reporting of dry mouth sensation will correlate with the total number of medications used."

\section{MATERIAL AND METHODS}

\section{Study design}

This study is a descriptive, secondary data analysis from a survey performed in $8 \mathrm{NF}$ from different cities in the Eastern part of the State of Iowa, USA; and $5 \mathrm{NF}$ from the city of Taubaté, State of Sao Paulo, Brazil. In both surveys, the same data regarding demographics, medications, medical conditions, denture status, teeth number, and xerostomia were recorded.

\section{Study participants}

Both surveys were approved by their respective Institutional Review Boards (IowaProtocol \# 201403778; SP Protocol \# 1.324.550). All involved NF agreed to participate, and all individual participants (or their guardians) signed informed consent forms.

The Iowan sample of $8 \mathrm{NF}$ was originally designed to be a part of a pilot study about the efficacy of a dental hygienist-delivered intervention to improve oral hygiene care, which was reported earlier [25]. Therefore, it was a convenience sample of NF located within a 75-minute driving distance of Iowa City that were not served by the University of Iowa Geriatric Mobile Unit (GMU) program. The GMU is a University of Iowa program that provides comprehensive care for nursing home residents in the Iowa City area. Among the 352 residents of the $8 \mathrm{NF}, 81$ were succesfully recruited. The Iowa clinical trial was registered at ClinicalTrials.gov (NCT02668809).

The Brazilian sample considered the number of institutionalized elderly people and the availability of the NF in Taubaté, and therefore was set at 123 individuals from which 119 were successfully recruited. 


\section{Data collection}

Demographics, medications, and medical conditions were collected from patients' medical records. Intra-oral exams were performed in a reserved room at the $\mathrm{NF}$, or at the patient's bedside, by one single trained examiner in each country with the help of a dental mirror and an external light source. Xerostomia was self-reported by having patients being asked the question: Do you feel your mouth dry? All data collected in Iowa were immediately added to a larger database housed in REDCap, a web application for building and managing online databases. All data collected in Sao Paulo were recorded on paper forms until they were later transferred to an Excel spreadsheet.

\section{Data analysis}

Descriptive statistics were prepared for demographic and health information. Comparisons between groups were made using the Wilcoxon Rank Sum test and the Chi-square test. All analyses were conducted using SAS 9.4 (Cary, NC) at the $5 \%$ level of significance.

\section{RESULTS}

Table 1 presents the descriptive data from both countries and the results of their comparison tests. The US group $(\mathrm{N}=81)$ had a mean age of 82.1 years ( \pm 12.9 years), $60.5 \%$ were females, and $100 \%$ were white, whereas the Brazilian group $(\mathrm{N}=119)$ had a mean age of 76.4 years ( \pm 8.7 years), $47.9 \%$ females, and participants identified as white $(42.0 \%)$, more than one race (45.4\%), African (7.6\%), native indian (3.4\%), and unknown (1.7\%).

The two groups differ regarding to age (Iowans being older), BMI (Iowans having higher BMI), number of medical conditions and medication (Iowans having more medical conditions and taking more medications). Additionally, xerostomia was significantly different among the two samples, being reported by $32.1 \%$ of the participants in the US, and by $59.7 \%$ in Brazil. Brazilians wore more upper and lower dentures than Iowans, as a consequence of having less teeth.
Regarding the source of payment for the $\mathrm{NF}$, private pay was the most common source for Iowa residents (45.7\%), followed by Medicaid (25.9) and Medicare (13.6). Medicaid is a USA government program that pays health care costs for disabled individuals of all ages, and Medicare is a US government program that pays health care costs for individuals that are 65-year old or older. In Brazil, $77.3 \%$ were residing in private pay NF and $22.7 \%$ in public NF (government run $\mathrm{NF}$, no out of pocket expenses for the resident or resident's family).

Table 2 presents the ten most common medical conditions in each sample, and the proportion of participants affected by them. The median number of medical conditions in the US was 9 ( $\min 1$, max 31), as compared to 2 (min 0, max 5) in Brazil. The most common medical conditions in the US were hypertension, dementia, depression, gastro-esophageal reflux, constipation, and type 2 diabetes mellitus. In Brazil, they were hypertension, unspecified diabetes mellitus, Parkinsonism, depression, peripheral vascular disease, and hypothyroidism.

Table 3 presents the ten most common medications in each sample and the proportion of participants taking them. The median number of medications for the US residents was 12 ( $\min 1$, $\max 24)$, as compared to $6(\min 1, \max 16)$ in Brazil. The most common prescription medications in the US were acetaminophen, acetylsalicylic acid, magnesium hydroxide, polyethylene glycol, docusate, and furosemide. In Brazil, they were omeprazole, acetylsalicylic acid, losartan, simvastatin, metformin, and captopril.

Among the most commonly used drugs, there are many medications with potential xerostomic effect, as antidepressant (lorazepam) and antihypertensive (furosemide, losartan, hydrochlorothiazide) drugs. Therefore, there was a significant positive association between total number of medications and xerostomia in Iowa $(\mathrm{p}=0.040)$, but not in Brazil $(\mathrm{p}=0.075)$, although the latter result was somewhat suggestive.

Conversely, there was no association between age and xerostomia in either the Iowa $(\mathrm{p}=0.480)$ or the Sao Paolo $(\mathrm{p}=0.130)$ samples. 
Table 1 - Descriptive statistics for the selected demographic, systemic health and oral health variables in the nursing facility residents from the states of lowa, USA, and Sao Paulo, Brazil

\begin{tabular}{|c|c|c|c|}
\hline & $\begin{array}{l}\text { lowa } \\
(\mathrm{N}=81)\end{array}$ & $\begin{array}{c}\text { Sao Paulo } \\
(N=119)\end{array}$ & P-value* \\
\hline Mean Age (SD), in years & $82.1( \pm 12.9)$ & $76.4( \pm 8.7)$ & $<0.0001$ \\
\hline$\%$ of females & 60.5 & 47.9 & 0.0798 \\
\hline BMI & $27.8( \pm 7.4)$ & $23.8( \pm 3.9)$ & $<0.0001$ \\
\hline Number of medical conditions & $9.8( \pm 5.3)$ & $2.2( \pm 1.4)$ & $<0.0001$ \\
\hline Number of medications & $12.3( \pm 5.4)$ & $6.2( \pm 3.7)$ & $<0.0001$ \\
\hline $\begin{array}{l}\% \text { of individuals reporting } \\
\text { xerostomia }\end{array}$ & 32.1 & 59.7 & 0.0002 \\
\hline $\begin{array}{l}\% \text { of individuals wearing upper } \\
\text { dentures }\end{array}$ & 43.2 & 73.9 & $<0.0001$ \\
\hline $\begin{array}{l}\% \text { of individuals wearing lower } \\
\text { dentures }\end{array}$ & 29.6 & 55.5 & 0.0003 \\
\hline Number of teeth & $14.5( \pm 10.5)$ & $3.2( \pm 6.8)$ & $<0.0001$ \\
\hline
\end{tabular}

${ }^{*}$ Groups were compared using the Wilcoxon Rank Sum test or the Chi-square test.

Table 2 - Ten most common medical conditions observed for nursing home residents from the states of lowa, USA, and Sao Paulo, Brazil; and the proportion of participants affected by them.

\begin{tabular}{|c|c|c|c|c|c|}
\hline lowa & $N=81$ & $\%$ & Sao Paulo & $\mathrm{N}=119$ & $\%$ \\
\hline $\begin{array}{l}\text { Essential (primary) } \\
\text { hypertension }\end{array}$ & 59 & 72.84 & $\begin{array}{l}\text { Essential } \\
\text { (primary) hyper- } \\
\text { tension }\end{array}$ & 63 & 52.94 \\
\hline $\begin{array}{l}\text { Unspecified de- } \\
\text { mentia }\end{array}$ & 40 & 49.38 & $\begin{array}{l}\text { Unspecified dia- } \\
\text { betes mellitus }\end{array}$ & 32 & 26.89 \\
\hline $\begin{array}{l}\text { Depressive epi- } \\
\text { sode }\end{array}$ & 36 & 44.44 & $\begin{array}{l}\text { Parkinson } \\
\text { disease }\end{array}$ & 12 & 10.08 \\
\hline $\begin{array}{l}\text { Gastro-oesopha- } \\
\text { geal reflux disease }\end{array}$ & 28 & 34.57 & $\begin{array}{l}\text { Depressive } \\
\text { episode }\end{array}$ & 10 & 8.40 \\
\hline Constipation & 26 & 32.10 & $\begin{array}{l}\text { Peripheral vas- } \\
\text { cular disease, } \\
\text { unspecified }\end{array}$ & 8 & 6.72 \\
\hline $\begin{array}{l}\text { Type } 2 \text { diabetes } \\
\text { mellitus }\end{array}$ & 21 & 25.93 & $\begin{array}{l}\text { Hypothyroidism, } \\
\text { unspecified }\end{array}$ & 7 & 5.88 \\
\hline $\begin{array}{l}\text { Anxiety disorder, } \\
\text { unspecified }\end{array}$ & 18 & 22.22 & $\begin{array}{l}\text { Pure hypercho- } \\
\text { lesterolaemia }\end{array}$ & 7 & 5.88 \\
\hline $\begin{array}{l}\text { Hyperlipidaemia, } \\
\text { unspecified }\end{array}$ & 18 & 22.22 & $\begin{array}{l}\text { Renal insuffi- } \\
\text { ciency }\end{array}$ & 7 & 5.88 \\
\hline $\begin{array}{l}\text { Iron deficiency } \\
\text { anaemia }\end{array}$ & 17 & 20.99 & $\begin{array}{l}\text { Gastro-oeso- } \\
\text { phageal reflux } \\
\text { disease }\end{array}$ & 6 & 5.04 \\
\hline $\begin{array}{l}\text { Congestive heart } \\
\text { failure }\end{array}$ & 15 & 18.52 & $\begin{array}{l}\text { Cerebrovascular } \\
\text { disease, unspe- } \\
\text { cified }\end{array}$ & 6 & 5.04 \\
\hline
\end{tabular}

Table 3 - Ten most common medications in the records for nursing home residents from the states of lowa, USA, and Sao Paulo, Brazil; and the proportion of participants taking them

\begin{tabular}{|cccccc|}
\hline lowa & $\mathbf{N = 8 1}$ & $\%$ & Sao Paulo & N=119 & $\%$ \\
\hline Acetaminophen & 69 & 85.19 & Omeprazole & 39 & 32.77 \\
\hline $\begin{array}{c}\text { Acetylsalicylic acid } \\
\text { Magnesium hy- }\end{array}$ & 37 & 45.68 & $\begin{array}{c}\text { Acetylsalicylic } \\
\text { Acid }\end{array}$ & 38 & 31.93 \\
\hline $\begin{array}{c}\text { droxide } \\
\text { Polyethylene glycol }\end{array}$ & 35 & 45.68 & Losartan & 34 & 28.57 \\
\hline Docusate & 22 & 27.16 & Metformin & 23 & 19.33 \\
\hline Furosemide & 22 & 27.16 & Captopril & 20 & 16.81 \\
\hline Omeprazole & 22 & 27.16 & $\begin{array}{c}\text { Hydrochloro- } \\
\text { thiazide }\end{array}$ & 19 & 15.97 \\
\hline Bisacodyl & 21 & 25.93 & Furosemide & 18 & 15.13 \\
\hline Lorazepam & 21 & 25.93 & Multivitamin & 18 & 15.13 \\
\hline Albuterol & 20 & 24.69 & Clonazepam & 14 & 11.76 \\
\hline
\end{tabular}

\section{DISCUSSION}

Our hypothesis that more co-morbidities would be found and more medications are taken among the American population was confirmed. Brazil and the US share some comorbidities such as hypertension, diabetes mellitus, and depression. However, the mean number of comorbidities is higher in Iowa than in Sao Paulo. Considering the increased number of comorbidities in the US sample, it was predictable that American institutionalized elders take more medications as compared to their Brazilian counterparts.

It was interesting to notice that although hypertension was cited as the most common disease in both samples, antihypertensive drugs were not on the top of the medication lists. The multitude of antihypertensive drugs and the fact that antihypertensive drugs are many times combined in different ways make their individual prescription numbers go down. Consequently, a single antihypertensive drug does not make it to the top of the medication list.

There are still many barriers for Brazilians institutionalized elders to access appropriate health care [7]. Fewer physician visits may result in fewer prescribed medications, and furthermore, 
the lower economic budget of Brazilian institutions plays a very important role in medication selection and purchasing [9]. The lower the cost, the more common the use of a given medication. While the lower numbers of medications used in the Brazilian population may be seen as positive, as it might reflect a more positive state of health and polypharmacy risks are reduced, it may not paint the most accurate picture. The Brazilian elderly and low income population often go without necessary medications, as certain medications may not be paid for unless designated as "essential medications" by the Brazilian Ministry of Health [23]. However, we cannot rule out that physicians in the US may be more apt to over-diagnose and consequently overmedicate, while physicians in Brazil may be under-diagnosing, leading to the differences we have observed. As the Brazilian elderly population increases and access to health care improves, it is important to be alert for the risks of over diagnosing and over medicating.

Our second hypothesis, that the more medications people take the higher the prevalence of xerostomia, was supported in the Iowa sample. However, the results in the SP sample was also suggestive, what points to questionable clinical significance of this result. It was no surprise, as medications with potential xerostomic effect [9], as antidepressant drugs (lorazepam) and antihypertensive drugs (furosemide, losartan, and hydrochlorothiazide) were among the most commonly prescribed on both samples. In addition, it was found that the number of individuals with a dementia diagnosis is higher in Iowa when compared to Brazil, and because dry mouth was self-reported, we cannot rule out greater misreporting of xerostomia status in the Iowa sample.

Regarding to other oral health-related findings, Brazilians presented with less teeth and were consequently wearing more dentures as compared to their Iowa counterparts, which was consistent with a previous report. [20] When comparing Sao Paulo and Iowa's elderly population, we also noticed that the proportion of NF residents successfully recruited were very different, i.e. 23\% (81/352) in Iowa and 97\%
$(119 / 123)$ in Sao Paulo. This difference is possibly caused by cultural or value-based underlying issues. Furthermore, this study's interpretation is limited by its modest sample sizes and geographic specificity, so generalizability should be interpreted with caution. Although we found evidence of significant statistical associations, these cannot be taken as support for causal effects. The study's cross-sectional design did not allow us to conclude any causal effect between number of medications and xerostomia, but rather point out possible statistical association between these two variables.

Future studies should focus on exploring the reasons for such a difference among the number of comorbidities, number of medications, and the effects of multiple medications on the number of institutionalized elderly patients reporting dry mouth.

\section{CONCLUSION}

Iowa nursing facility residents presented with higher numbers of comorbidities and prescription medications, but xerostomia was reported in a greater proportion by Brazilians. There was no association between age and dry mouth sensation in both samples. However, there was a positive association between total number of medications and dry mouth sensation among the Iowan sample. Among the Brazilian sample, the statistical threshold for the same association was not reached, but it was quite close.
Abbreviations
USA-United States of America
SP- Sao Paulo
NF- Nursing facilities
GMU - Geriatric mobile unit
REDCap - Research Electric Data Capture

\section{Ethics approval and consent to participate}

The study was approved by the University of Taubate Research Ethics Committee (\#1.324.550) and University of Iowa Institutional Review Board 
(IRB ID \# 201403778).

\section{Availability of data and materials}

The datasets used and/or analyzed during the current study are available from the corresponding author on reasonable request.

\section{Competing interests}

The authors declare that they have no competing interests

\section{Funding}

Delta Dental of Iowa Foundation, the University of Iowa College of Dentistry and Dental Clinics, and Sao Paulo Research Foundation provided generous support of this study. However, they did not participate in the design of the study and collection, analysis, and interpretation of data and in writing this manuscript.

\section{Authors' contributions}

ER- Subject recruitment (USA), data collections (USA), analysis and preparation of paper

MSSM - Subject recruitment (Brazil), data collections (Brazil), analysis and preparation of paper

DRB -Statistical design, analysis and preparation of paper

DVD - Statistical design, analysis and preparation of paper

HC - Methodological design, data collections (USA), analysis and preparation of paper

$\mathrm{JH}$ - Methodological design, data collections (USA), analysis and preparation of paper

JFFS- Methodological design, data collections (Brazil), analysis and preparation of paper

LNC - Subject recruitment (Brazil), data collections (Brazil), analysis and preparation of paper

DJC - Study inception and methodological design, analysis and preparation of paper

LM - Study inception and methodological design, coordination between US-Brazil, subject recruitment (USA), data collections (USA), analysis and preparation/submission/correspondence of paper

\section{ACKNOWLEDGEMENTS}

The authors would like to thank all participating nursing facilities as well as Ms. Heather Stallman, Mary-Kelly Grief and Allison Winter for their help. The authors also would like to thank the Delta Dental of Iowa Foundation, the University of Iowa College of Dentistry and Dental Clinics, and Sao Paulo Research Foundation for their generous support of this study. Research reported in this publication utilized REDCap and was also supported by the National Center for Advancing Translational Sciences of the National Institutes of Health under Award Number U54TR001356. The content is solely the work of the authors and does not necessarily represent the official views of the National Institutes of Health.

\section{REFERENCES}

1. WHO. World report on ageing and health. World Health Organization; 2015: p260.

2. USCensusBureau. Older Americans Month: May 20172017 [Available from: https://www.census.gov/content/dam/Census/newsroom/ facts-for-features/2017/cb17-ff08.pdf.

3. IBGE. Pesquisa Nacional por Amostra de Domicilios: Sintese de indicadores 2014. Rio de Janeiro: Instituto Brasileiro de Geografia e Estatistica; 2015

4. USDepartmentofState. Why Population Aging Matters: A Global Perspective. 2007.

5. Ipea Instituto de Pesquisa Econômica Avançada. Condicoes de funcionamento e infraestrutura das instituicoes de longa permanencia para idosos no Brasil. Creative Commons; 2011: p17.

6. CMS Centers for Medicare and Medicaid Services. Nursing Home Data Compendium. 2015.

7. de Deco CP, do Santos JF, da Cunha Vde P, Marchini L. General health of elderly institutionalised and community-dwelling Brazilians. Gerodontology. 2007 Sep;24(3):136-42. 
8. Sansoni J, Anderson KH, Varona LM, Varela G. Caregivers of Alzheimer's patients and factors influencing institutionalization of loved ones: some considerations on existing literature. Ann Ig. 2013 May-Jun;25(3):235-46. doi: 10.7416/ai.2013.1926.

9. Marchini A, de Deco C, Silva M, Lodi K, da Rocha R, Marchini L. Use of Medicines Among a Brazilian Elderly Sample: A Cross-sectional Study. Int J Gerontology. 2011;5(2):94-7.

10. Fischer D, Ship JA. Effect of age on variability of parotid salivary gland flow rates over time. Age Ageing. 1999;28(6):557-61.

11. Nassar M, Hiraishi N, Islam MS, Otsuki M, Tagami J. Age-related changes in salivary biomarkers. J Dent Sci. 2014;9(1):85-90.

12. Cunning DM, Lipke N, Wax MK. Significance of unilateral submandibular gland excision on salivary flow in noncancer patients. Laryngoscope. 1998;108(6):812-5.

13. Saito M, Shimizu Y. Age-related changes in cellular activity in human submandibular glands as evaluated by argyrophilic nucleolar organizer regions. Gerodontology. 1999;16(1):29-36.

14. Kitasako Y, Ikeda M, Burrow MF, Tagami J. Oral health status in relation to stimulated saliva buffering capacity among Japanese adults above or below 35 years of age. J Med Dent Sci. 2006;53(4):175-80.

15. Leal SC, Bittar J, Portugal A, Falcao DP, Faber J, Zanotta P. Medication in elderly people: its influence on salivary pattern, signs and symptoms of dry mouth. Gerodontology. 2010;27(2):129-33.

16. Guggenheimer J, Moore PA. Xerostomia: etiology, recognition and treatment. J Am Dent Assoc. 2003;134(1):61-9; quiz 118-9.

17. Scannapieco FA, Cantos A. Oral inflammation and infection, and chronic medical diseases: implications for the elderly. Periodontol 2000. 2016;72(1):153-75.

18. Donnelly LR, MacEntee MI. Social interactions, body image and oral health among institutionalised frail elders: an unexplored relationship. Gerodontology. 2012;29(2):e28-33.
19. Kelly MC, Caplan DJ, Bern-Klug M, Cowen HJ, Cunningham-Ford MA, Marchini L, et al. Preventive dental care among Medicaid-enrolled senior adults: from community to nursing facility residence. J Public Health Dent. 2018 Dec;78(1):86-92. doi: 10.1111/jphd.12247. Epub 2017 Sep 8.

20. Marchini L, Vieira PC, Bossan TP, Montenegro FL, Cunha VP. Selfreported oral hygiene habits among institutionalised elderly and their relationship to the condition of oral tissues in Taubate, Brazil. Gerodontology. 2006;23(1):33-7.

21. De Visschere LM, Grooten L, Theuniers G, Vanobbergen JN. Oral hygiene of elderly people in long-term care institutions--a crosssectional study. Gerodontology. 2006;23(4):195-204.

22. Watkins C, Ettinger RL, Cowen H, Qian F, Dawson DV. lowa dentists involvement in care for patients who are homebound. Spec Care Dentist. 2012;32(6):251-8.

23. Paula SBd, Mendonça PFB, Santos MBFd, Santos JFF, Marchini L. Evaluation of health parameters, use of drugs, and alcohol intake among an elderly population in São José dos Campos, SP, Brazil. Braz J Oral Sci. 2014;13(1):76-82.

24. de Deco CP, Reis MRVS, Marchini AMPS, da Rocha RF, dos Santos MBF, Marchini L. Taste alteration, mouth dryness and teeth staining as side effects of medications taken by elderly. Braz J Oral Sci. 2014;13(4):25760.

25. Marchini L, Recker E, Hartshorn J, Cowen H, Lynch D, Drake D, et al. lowa nursing facility oral hygiene (INFOH) intervention: A clinica and microbiological pilot randomized trial. Spec Care Dentist. 2018 Nov;38(6):345-355. doi: 10.1111/scd.12327. Epub 2018 Sep 8.

\section{Leonardo Marchini}

(Corresponding address)

Department of Preventive Dentistry, University of Iowa College of Dentistry \& Den-

tal Clinics, 801 Newton Road, Iowa City, IA-52242.

Dr. Leonardo Marchini / leonardo-marchini@uiowa.edu

Date submitted: 2018 0ct 15

Accept submission: 2018 Jan 21 